\title{
Propionibacterium freudenreichii strains quantitatively affect production of volatile compounds in Swiss cheese
}

\author{
Anne THIERRYa*, Marie-Bernadette MAILLARD ${ }^{\mathrm{a}}$, Romain RICHOUX ${ }^{\mathrm{b}}$, \\ Jean-René KERJEAN ${ }^{\mathrm{b}}$, Sylvie LORTAL ${ }^{\mathrm{a}}$ \\ a UMR Science et Technologie du Lait et de l'Oeuf, INRA-Agrocampus Rennes, 65 rue de Saint-Brieuc, \\ 35042 Rennes Cedex, France \\ b Institut Technique Français des Fromages, BP 50915, 35009 Rennes Cedex, France
}

\begin{abstract}
Cheese flavour is the result of a complex mixture of volatile compounds, originating mainly from the enzymatic degradation of curd components by cheese microflora during cheese ripening. Directing cheese flavour development requires knowledge on inter- and intra-species contributions to flavour development, i.e. identification of the volatile (flavour) compounds produced by each strain. The aim of this study was to identify the volatile compounds produced in Swiss cheese by Propionibacterium freudenreichii, one of the species essential for the development of the characteristic flavour of this type of cheese. The volatile profile of compounds obtained from smallscale (1/100) Swiss cheeses, with or without $P$. freudenreichii, were compared (three strains tested, in association with three thermophilic lactic starters, i.e. twelve cheeses, manufactured in duplicate). Neutral volatile compounds, extracted by dynamic headspace, and free fatty acids were identified using gas chromatography-mass spectrometry. The concentrations of all carboxylic acids and 14 of 58 neutral compounds were significantly higher in the presence of propionibacteria (PAB). The three PAB strains tested produced the same volatile compounds, but observed quantitative differences were strain-dependent. Propionic acid and four propionate esters were detected only in the presence of PAB. Moreover, cheeses with PAB contained two- to three- fold higher levels of free fatty acids derived from lipolysis and five- to fifty- fold higher levels of branched-chain compounds derived from isoleucine catabolism (2-methylbutanal, 2-methylbutanol and 2-methylbutanoic acid) and from leucine catabolism (3-methylbutanoic acid). Lactic starters induced significant variations in the concentrations of some of the compounds produced by PAB, such as methylbutanoic acids and free fatty acids, which varied by 2.0 and 1.4, respectively, as a function of the lactobacilli strains. PAB strains affect the concentration of varied volatile compounds and could therefore have distinct contributions to the formation of Swiss cheese flavour.
\end{abstract}

\section{Propionibacterium freudenreichii / volatile compound / Swiss cheese}

Résumé - Les souches de Propionibacterium freudenreichii influencent la concentration de composés volatils variés dans l'emmental. Pour maîtriser la formation de la flaveur du fromage, qui est due à une multitude de composés volatils essentiellement produits par la microflore au cours de l'affinage, il est nécessaire de déterminer comment chaque espèce et souche contribue à la formation de composés d'arôme. L'objectif de cette étude était d'identifier les composés volatils produits dans l'emmental par Propionibacterium freudenreichii, une espèce clé du développement de la flaveur caractéristique de ce fromage. Douze mini-emmentals (échelle 1/100) ont été fabriqués en double, en associant $P$. freudenreichii (trois souches) et un témoin sans propionibactéries, à trois

\footnotetext{
* Corresponding author: anne.thierry@ rennes.inra.fr
} 
levains lactiques. Les composés volatils neutres de ces fromages et les acides gras libres ont été analysés par chromatographie en phase gazeuse. Seuls les fromages ensemencés en propionibactéries contenaient de l'acide propionique et quatre esters de propionate. Ces fromages contenaient également 2 à 3 fois plus d'acides gras libres et 5 à 50 fois plus de composés ramifiés volatils issus du catabolisme de l'isoleucine (2-méthylbutanal, 2-méthylbutanol et acide 2-méthylbutanoïque) et de la leucine (acide 3-méthylbutanoïque), avec des différences très significatives selon les souches. Les lactobacilles associés modulaient les concentrations de certains composés produits par $P$. freudenreichi (acides méthylbutanoïques et acides gras libres). Les souches de $P$. freudenreichi, en faisant varier la concentration de divers composés volatils, pourraient avoir des contributions distinctes à la formation de la flaveur de l'emmental.

\section{Propionibacterium freudenreichii / composé volatil / emmental}

\section{INTRODUCTION}

Mature cheeses contain a wide range of flavour compounds, including volatile and non-volatile compounds [13, 49]. The flavour-active compounds have been identified in several cheese varieties, including Emmental, Gruyere and Camembert cheese [24, 33, 34, 38]. Most of these compounds originate from the action of the cheese microflora and their enzymes on lactose, lactate, lipids and proteins of cheese curd [30]. Cheese is a microbial ecosystem that evolves throughout manufacture and ripening, where complex interactions between microflora generally occur [5]. Several species and strains may be involved in the pathway of formation of flavour compounds, as shown for the formation of volatile compounds derived from amino acid catabolism by lactic acid bacteria $[1,21]$. To control or modify cheese flavour development, an understanding of the role of cheese microflora and of their interactions in the formation of flavour compounds is necessary.

The flavour of Swiss cheese is comprised of various compounds, such as furanones, short- to medium-chain acids, esters, diacetyl, and branched-chain (BC) aldehydes [33, $34,39]$. Two main flora are known to be essential for the development of the characteristic flavour of Swiss cheese: thermophilic lactic acid bacteria and propionibacteria (PAB) [26, 32]. Thermophilic lactic acid bacteria (streptococci and lactobacilli) are specifically involved in the fermentation of lactose into lactic acid which occurs during curd acidification, within the first day of manufacture. They also have a major contribution to cheese proteolysis, and the activity of their enzymes results in the release of free amino acids, which are the precursors of many flavour compounds. Moreover, lactic acid bacteria are also capable of forming various volatile compounds, and in particular, significant amounts of carbonyl compounds [17, 19, 35, 48, 51]. PAB have been known for a long time to contribute to the development of Swiss cheese flavour and cheese opening, achieved through the fermentation of lactic acid into propionic acid, acetic acid and $\mathrm{CO}_{2}[6,18,40]$. More recently, PAB were shown to play a prominent role in the formation of free fatty acids (FFA) and of short BC acids that result from triglyceride hydrolysis and from leucine/ isoleucine catabolism, respectively [10, 41, 45]. The production in cheese of both FFA and short BC acids has been shown to be strain-dependent $[10,46]$. However, the possible contribution of $\mathrm{PAB}$ to the formation of other volatile compounds has not been fully investigated [31]. Thierry et al. first studied the ability of one strain of $P$. freudenreichii to produce volatile compounds in cheese, by comparing the profiles of volatiles of experimental Swiss-type cheeses manufactured with or without addition of $\mathrm{PAB}$, using headspace gas chromatographymass spectrometry [45]. The authors showed the contribution of this strain to the formation of a variety of volatiles, such as alcohols, esters and ketones, which were present at significantly greater concentrations in the 
presence of $\mathrm{PAB}$ than in the control cheeses without $P A B$. No data are available regarding the possible influence of $\mathrm{LAB}$ on $\mathrm{PAB}$ activity, although the existence of lactobacilli-PAB interactions in cheese has been reported [2, 9, 16, 31].

The aim of the present study was to determine the contribution of PAB to the formation of Swiss cheese volatile compounds and to evaluate the effect of $\mathrm{PAB}$ strains and of thermophilic lactobacilli-PAB interactions on the volatiles produced. To this end, three strains of $P$. freudenreichii and one control without PAB were each associated with three different thermophilic lactic starters in controlled-flora mini-Swiss cheeses, and the acidic and neutral volatile compounds quantified at two ripening stages.

\section{MATERIALS AND METHODS}

\subsection{Cheese starters}

All the lactic and propionic strains used in this study were obtained from the collection of the Institut Technique Français du Fromage (Rennes, France), except the starter LH100 (a mixture of strains of Lactobacillus helveticus and Lactobacillus delbrueckii subsp. lactis), which was obtained from Rhodia-Food (Dangé Saint-Romain, France). The other lactic starters used were Lactobacillus helveticus ITGLH56 and ITGLH77, Lactobacillus delbrueckii subsp. lactis ITGLL57 and Streptococcus thermophilus ITGST82 and ITGST87. Three Propionibacterium freudenreichii strains (ITGP14, ITGP17 and ITGP23) were chosen from previous screening experiments in mini-Swiss cheeses as they showed similar kinetics of propionic fermentation $[36,37]$ and different abilities to produce 2-methylbutanoic/3-methylbutanoic acids [47].

\subsection{Cheese manufacture}

Small-scale (1/100) experimental Swiss cheeses were manufactured from thermised and microfiltered milk according to a standardised cheese-making process previously described [36, 37, 46]. Cheeses were man- ufactured according to a factorial experimental design where two factors, lactic starter and propionic starter, were studied. Three lactic starters (LH100, ITGLH56 + ITGLL57 and ITGLH77, each associated with ITGST82 + ITGST87) were combined with three PAB strains (ITGP14, ITGP17 and ITGP23) and one control cheese without PAB, resulting in twelve starter associations. Two batches of each of the twelve cheeses $(800 \mathrm{~g})$ were manufactured on two different days, over a period of five weeks in December and January. Each cheese was brined on day one and then divided into one cheese block of $400 \mathrm{~g}$ and 8 sectors of $50 \mathrm{~g}$ before being wrapped under vacuum in a Cryovac BK1L film (Cryovac-Europe, Épernon, France). The cheese ripening conditions used were similar to those of industrial cheese-making, ripening at $12{ }^{\circ} \mathrm{C}$ for $21 \mathrm{~d}$, then transferred to $24^{\circ} \mathrm{C}$ (warm room) until $80 \%$ of the initial lactic acid had been utilised. To achieve this, the increase in cheese volume, determined by immersion of the cheese in water as previously described [37], was followed for the 400-g cheeses. As soon as their volume had increased by 2 $3 \%$, i.e. after $2-11 \mathrm{~d}$ depending on the $\mathrm{PAB}$ strains, two sectors were taken from the warm room, one for control of propionic fermentation and the other one placed at $4{ }^{\circ} \mathrm{C}$ for 8 weeks of cold ripening. The same operation was renewed three times at 2- to 3 -d intervals for the $3 \times 2$ resting sectors. For each of the 24 cheeses, the four sectors sampled during the ripening in the warm room were analysed for their content in organic acids by HPLC as described hereafter. The samples containing approximately $20 \%$ of the initial content of lactic acid were chosen to be further analysed for FFA and neutral volatile compounds. The corresponding samples were taken from cold ripening after 8 weeks. All the samples were kept frozen at $-80{ }^{\circ} \mathrm{C}$ until analysis.

\subsection{Compositional analysis}

Samples of ripened cheeses were analysed for moisture (oven drying at $103{ }^{\circ} \mathrm{C}$ ), 
for protein (Kjeldahl), fat (Heiss butyrometric method) and $\mathrm{pH}$ by classical methods as previously described [37]. Carboxylic acids (lactic, propionic and acetic acids) were determined in cheese homogenate, prepared as described in 2.5 for neutral volatile compound analysis, by HPLC on an Aminex A-6 ion exchange column (BioRad, Hercules, CA, USA) at $55^{\circ} \mathrm{C}$ with 0.01 $\mathrm{NH}_{2} \mathrm{SO}_{4}$ as eluent, at a flow rate of $1.0 \mathrm{~mL} \cdot \mathrm{min}^{-1}$. Both UV $(210 \mathrm{~nm})$ and refractometric detectors were used. Acetic and propionic acids were also determined by gas chromatography as previously described [46].

\subsection{Microbiological analyses}

For microbiological analyses, performed after 2 weeks of ripening in the warm room, samples of cheeses $(20 \mathrm{~g})$ were dispersed in $180 \mathrm{~g}$ of a $2 \%$ sodium citrate solution, homogenised, diluted with peptone saline solution and plated on specific media. Propionibacteria were enumerated on lithium-glycerol agar [42] incubated at $30^{\circ} \mathrm{C}$ anaerobically for $6 \mathrm{~d}$. Non-starter lactic acid bacteria, which can grow in cheeses during the ripening, were enumerated on $\mathrm{FH}$ agar [20] incubated at $30{ }^{\circ} \mathrm{C}$ anaerobically for $3 \mathrm{~d}$ and on MRS agar incubated at $15^{\circ} \mathrm{C}$ anaerobically for $14 \mathrm{~d}[46]$.

\subsection{Determination of volatile compounds}

FFA $\left(\mathrm{C}_{4: 0}\right.$ to $\mathrm{C}_{20: 1}$, including $i \mathrm{C}_{5: 0}+$ $a \mathrm{C}_{5: 0}$ and conjugated linoleic acid) analyses were performed by gas chromatography (GC) by ITERG (Pessac, France) according to De Jong and Badings [14]. Briefly, FFA were extracted from the cheese with etherheptane after grinding with sodium sulphate and addition of sulphuric acid, isolated from lipids using an aminopropyl column and analysed by GC under the following conditions: cooler on-column injector, column: QUADREX - FFAP capillary column, $30 \mathrm{~m} \times 0.32 \mathrm{~mm} \times 0.25 \mu \mathrm{m}$ film thickness; carrier gas: hydrogen, 1.1 bar; temperature programme, heating rate: $10{ }^{\circ} \mathrm{C} \cdot \mathrm{min}^{-1}$ from $50{ }^{\circ} \mathrm{C}$ up to $240{ }^{\circ} \mathrm{C}$, maintained for $15 \mathrm{~min}$, flame-ionisation detector operated at $260{ }^{\circ} \mathrm{C}$. As the chromatographic conditions did not efficiently separate 2-methylbutanoic acid from 3-methylbutanoic acid, the proportion of these two acids was obtained by determining the proportion of their respective methyl ester. Methyl esters were synthesised according to the method of Beck et al. [3], with the following modifications: $1 \mathrm{~mL}$ of cheese homogenate, $1 \mathrm{~mL}$ of a saturated solution of $\mathrm{NaHSO}_{4}$ and $1 \mathrm{~mL}$ of a $205 \mathrm{mg} \cdot \mathrm{L}^{-1}$ methanol solution were mixed in a $9-\mathrm{mL}$ pyrex tube. The esterification reaction was performed by placing the closed tube in a water bath at $90{ }^{\circ} \mathrm{C}$ for $2 \mathrm{~h}$. The two methyl esters of methylbutanoic acids, i.e. methyl 2-methylbutanoate and methyl 3-methylbutanoate, were extracted by dynamic headspace and analysed by gas chromatography as described in the next section, and quantified by the ions 88 and 74, respectively. Samples of control cheese homogenates were spiked with $50 \mathrm{mg} \cdot \mathrm{kg}^{-1}$ of methylbutanoic acids containing varying proportions of the two isomers $(0: 100,25: 75,50: 50$, $75: 25$ and 100:0) and were subjected to esterification as described above. Data were used to determine the regression curve of the proportion of acid isomers consisted of 2-methylbutanoic acid (y) and the proportion of ester isomers consisted of methyl 2methylbutanoate $(\mathrm{x})$. The equation obtained $\left(y=1.047 x, R^{2}=0.9928\right)$ shows that the proportion of the two ester isomers synthesised fitted with the proportion of the two acid isomers that were added.

Neutral volatile compounds were identified and quantified by dynamic headspace GC-MS. Before analysis, cheese samples were thawed and cut into cubes $(2.5 \mathrm{~mm} \times$ $2.5 \mathrm{~mm} \times 2.5 \mathrm{~mm}$ ) which were mixed. A $15 \mathrm{~g}$ sample was homogenised with $60 \mathrm{~g}$ of $0.5 \mathrm{~mol} \cdot \mathrm{L}^{-1}$ sodium citrate solution by mixing for $4 \mathrm{~min}$ at $20500 \mathrm{rpm}$ using an Ultraturrax blender (Janke \& Kunkel, Staufen, Germany). A 7-g sample of this cheese homogenate $( \pm 0.05 \mathrm{~g})$ was used for each headspace GCMS analysis. Each sample was analysed in duplicate. Analyses were performed as described in detail previously [43]. Briefly, 
volatile compounds were trapped on a Vocarb 3000 trap (Supelco, Bella Fonte, PA, USA), thermally desorbed at $250{ }^{\circ} \mathrm{C}$ and cryofocused at $-100{ }^{\circ} \mathrm{C}$, before being injected into a HP5890 (Agilent Technologies, Palo Alto, CA, USA) gas chromatograph HP5972A quadrupole mass spectrometer (GC-MS). Volatiles were separated on a HP5 capillary column $(60 \mathrm{~m} \times 0.32 \mathrm{~mm} \times$ $1.0 \mu \mathrm{m}$ film thickness) under the following conditions: carrier gas: helium, $29 \mathrm{~cm} \cdot \mathrm{s}^{-1}$ at $35^{\circ} \mathrm{C}$; temperature programme: $35^{\circ} \mathrm{C}$ for 5 min, heating rate: $5^{\circ} \mathrm{C} \cdot \mathrm{min}^{-1}$ up to $140{ }^{\circ} \mathrm{C}$ then $15^{\circ} \mathrm{C} \cdot \mathrm{min}^{-1}$ up to $250{ }^{\circ} \mathrm{C}$. MS was operated in the scan mode within a mass range of $\mathrm{m} / \mathrm{z} 25-173$ at $4.83 \mathrm{scan} \cdot \mathrm{s}^{-1}$, after ionisation by electronic impact at $70 \mathrm{eV}$. Thirty-three compounds were identified by comparison of mass spectra and retention times with those of authentic standards. Twenty-three other compounds, for which standards were not available, were tentatively identified on the basis of mass spectral data from the Hewlett Packard Chemstation NIST 75K mass spectral Database. Twentythree neutral volatile compounds were quantified as follows. Peaks were quantified by the areas of either the total ion current (TIC) or selected fragments $(\mathrm{m} / \mathrm{z})$. To avoid the approximations related to the commonly used internal standard calibration [15], eight high purity chemicals (3-methylbutanal, 3-methylbutanol, ethyl acetate, ethyl propionate, ethyl butanoate, 2,3-butanedione, 2-heptanone and dimethyl disulphide), purchased from Sigma-Aldrich (St-QuentinFallavier, France) were used as external standards. Stock solutions of standard compounds were prepared in high purity $(99.8 \%)$ methanol at concentrations of 4 $7 \mathrm{mg} \cdot \mathrm{g}^{-1}$ and stored at $-20^{\circ} \mathrm{C}$. Amounts of each stock solution were used to prepare a standard mix containing 50 to $2500 \mu \mathrm{g} \cdot \mathrm{g}^{-1}$ of each standard compound. An aliquot $(\sim 15 \mathrm{mg})$ of standard mix was accurately weighed and used to spike a $35-\mathrm{g}$ sample of control cheese homogenate, resulting in final concentrations of 100 to $5000 \mu \mathrm{g} \cdot \mathrm{g}^{-1}$ cheese. Seven additional calibration standard solutions were prepared by further dilution (weight to weight) of the spiked cheese homogenate in blank cheese homogenate, in order to obtain eight different concentrations covering the following ranges: $0.8-100 \mathrm{ng} \cdot \mathrm{g}^{-1}$ cheese (dimethyl disulphide), $1.4-180 \mathrm{ng} \cdot \mathrm{g}^{-1}$ (3-methylbutanal), 8-1000 $\mathrm{ng} \cdot \mathrm{g}^{-1}$ (2-heptanone), 17-2200 ng.g ${ }^{-1}$ (ethyl acetate, ethyl propionate, ethyl butanoate, 3-methylbutanol), 40-5000 $\mathrm{ng} \cdot \mathrm{g}^{-1}$ (2,3-butanedione). Five compounds (3-methylbutanol, 3-methylbutanal, ethyl propionate, 2,3-butanedione and 2-heptanone) were quantified from the regression curve of the corresponding standard. Eighteen other compounds were quantified from the regression curves of closely related standards (same chemical function, close molecular mass), as follows: 2-methylbutanol, 2-butanol and 2-pentanol from 3-methylbutanol; 2-methylpropanal, 2-methylbutanal and pentanal from 3-methylbutanal; methyl propionate from ethyl acetate; n-propyl acetate from ethyl propionate; isopropyl propionate and propyl propionate from ethyl butanoate; 2-butanone and 2,3-pentanedione from 2,3-butanedione; 4-methyl-2-pentanone, 2-hexanone, 6-methyl2-heptanone, 5-methyl-2-heptanone and 2-octanone from 2-heptanone and dimethyl trisulphide from dimethyl disulphide.

\subsection{Statistical analyses}

Concentration data of each compound of duplicate cheeses were used for statistical analysis. Analyses of variance (ANOVA) were performed using the General Linear Model procedure of Statgraphics Plus (Statistical Graphic Corp., Englewood Cliffs, NJ, USA) to determine the effect of PAB strain, the effect of thermophilic lactic acid bacteria strains, and the effect of the interaction between $P A B$ and lactic acid bacteria strains on PAB growth and on the concentration of each volatile compound. Differences between the treatment means were compared at the 5\% level of significance using the Fisher's least significance difference (LSD) test.

The concentrations of compounds which did not significantly discriminate between 
cheeses $(P>0.01)$ were removed from the subsequent analyses. The data were then standardised (1/standard deviation) and Principal Component Analysis (PCA) was performed using Statbox (GrimmerSoft, Paris, France).

\section{RESULTS AND DISCUSSION}

\subsection{Cheese rough composition and microbiology}

The rough composition of the cheeses $(62.4 \pm 0.5 \%$ total solids, $45.6 \pm 0.5 \%$ fat in dry matter and $52.5 \pm 0.5 \%$ moisture in the non-fat substance) was consistent with the expected values for this type of minicheese $[36,46]$, and was not influenced by the lactic and propionic starters used (data not shown).

Non-starter lactic acid bacteria, enumerated on two different media in cheeses after 2 weeks of ripening in the warm room, were under detection level in half of the cheeses, irrespective of the starter added. Low numbers of non-starter lactic acid bacteria, ranging from $5 \times 10^{1}$ to $7 \times 10^{4}$ colony-forming units (cfu) per $g$ cheese, were found in the remainder of the cheeses. Indigenous PAB were not detected in cheeses that were not inoculated with PAB (control cheeses).

\subsection{Growth of propionibacteria and propionic fermentation}

In cheeses inoculated with $P$. freudenreichii, $\mathrm{PAB}$ numbers ranged from $4 \times 10^{9}$ to $7 \times 10^{9} \mathrm{cfu} \cdot \mathrm{g}^{-1}$ after $14 \mathrm{~d}$ in the warm room. ANOVA showed that PAB numbers were significantly $(P<0.001)$ influenced by the lactobacilli strains used, but not by the strain of PAB and by PAB-lactobacilli interactions. The absence of the effect of the strain of PAB on their levels was expected as the three PAB strains used in the present study were chosen from strains showing similar kinetics of propionic fermentation in this type of mini-Swiss cheese [36, 37]. Levels of PAB detected were, on average,
$50 \%$ higher in the presence of lactobacilli LH100 than in the presence of lactobacilli LH56-LL57; the third lactobacilli strain exhibited an intermediate behaviour in respect to its effect on PAB. The influence of lactobacilli was the same regardless of the strain of PAB used, which is in accordance with the absence of statistical PABlactobacilli interactions. The influence of thermophilic lactobacilli on PAB in cheese has been previously reported $[2,9,16]$. As a consequence of the influence of lactobacilli strains on propionic fermentation, using the same ripening period for cheeses containing different lactic strains can result in a bias of the results if the abilities of PAB strains to produce flavour compounds are to be compared.

The sampling procedures used in the present study were designed to counteract this bias, and cheeses were taken out of the warm room after a similar degree of propionic acid fermentation had been achieved, fixed at a level of $\sim 80 \%$ of the initial lactic acid utilised. This level of propionic fermentation, which corresponded to the production of around 550-600 mg propionic acid per 100 -g cheese, was achieved following a wide range of time periods in the warm room $(11.8 \pm 3.7 \mathrm{~d})$. These time periods were not affected by PAB strain but significantly $(P<0.05)$ depended on the lactic starter, with a mean time in the warm room of $9.3,11.3$, and $14.8 \mathrm{~d}$ in the presence of starters LH100, LH77, and LH56-LL57, respectively. This result is in agreement with the observed effect of lactic starters on PAB growth in the present study, and with previous works showing that lactobacilli can induce marked differences in kinetics of propionate formation in Swiss cheese [2, $9,16]$. As expected from the sampling procedure, the concentrations of propionic and acetic acids did not differ significantly at the end of the warm room ripening (Tab. I). The average values of acetic and propionic acids in cheeses containing PAB were $211 \pm$ 23.5 and $574 \pm 45.7 \mathrm{mg} \cdot 100 \mathrm{~g}^{-1}$, respectively, versus $50 \pm 15.6$ and $1 \pm 1.1 \mathrm{mg} \cdot 100 \mathrm{~g}^{-1}$, respectively, in the control cheeses. 
Table I. Effect of three Propionibacterium freudenreichii strains (P17, P23 and P14) on the formation of acids in mini-Swiss cheeses.

\begin{tabular}{|c|c|c|c|c|c|c|c|c|c|c|}
\hline \multirow[t]{2}{*}{ Acids $\left(\mathrm{mg} \cdot 100 \mathrm{~g}^{-1}\right)^{\mathrm{a}}$} & \multicolumn{5}{|c|}{ At the end of warm room period $b$} & \multicolumn{5}{|c|}{ After two months' storage at $4^{\circ} \mathrm{C}$ b } \\
\hline & $\mathrm{Ctrl}^{\mathrm{c}}$ & P17 & $\mathrm{P} 23$ & $\mathrm{P} 14$ & stat $^{d}$ & $\mathrm{Ctrl}^{\mathrm{c}}$ & $\mathrm{P} 17$ & $\mathrm{P} 23$ & $\mathrm{P} 14$ & stat ${ }^{d}$ \\
\hline Acetic acid $\left(\mathrm{C}_{2: 0}\right) \#$ & $49.7^{\mathrm{a}}$ & $219.2^{\mathrm{b}}$ & $209.9^{b}$ & $205.1^{b}$ & $* * *$ & 66.1 & $277.0^{\mathrm{b}}$ & $276.3^{b}$ & $263.8^{b}$ & $* * *$ \\
\hline Propionic acid $\left(\mathrm{C}_{3: 0}\right) \#$ & $1.1^{\mathrm{a}}$ & $608.5^{b}$ & $527.0^{\mathrm{b}}$ & $587.2^{b}$ & $* * *$ & 1.2 & $740.0^{\mathrm{b}}$ & $694.9^{\mathrm{b}}$ & $729.4^{b}$ & $* * *$ \\
\hline $\begin{array}{l}\text { 3-Methylbutanoic acid } \\
\left(i \mathrm{C}_{5: 0}\right) \dagger\end{array}$ & $0.2^{\mathrm{a}}$ & $0.2^{\mathrm{a}}$ & $0.2^{\mathrm{a}}$ & $0.5^{b}$ & ** & $0.1^{\mathrm{a}}$ & $0.2^{\mathrm{a}}$ & $0.6^{\mathrm{b}}$ & $1.5^{\mathrm{c}}$ & $* * *$ \\
\hline $\begin{array}{l}\text { 2-Methylbutanoic acid } \\
\left(a \mathrm{C}_{5: 0}\right) \dagger\end{array}$ & $0.0^{\mathrm{a}}$ & $0.4^{\mathrm{b}}$ & $0.5^{b}$ & $1.5^{\mathrm{c}}$ & $* * *$ & $0.1^{\mathrm{a}}$ & $0.9^{\mathrm{b}}$ & $1.8^{\mathrm{c}}$ & $3.3^{\mathrm{d}}$ & $* * *$ \\
\hline Butanoic acid $\left(\mathrm{C}_{4: 0}\right)$ & $1.5^{\mathrm{a}}$ & $3.2^{b}$ & $3.5^{b}$ & $3.7^{\mathrm{b}}$ & $* * *$ & $2.6^{\mathrm{a}}$ & $5.0^{\mathrm{b}}$ & $6.0^{\mathrm{c}}$ & $5.3^{b c}$ & $* * *$ \\
\hline Hexanoic acid $\left(\mathrm{C}_{6: 0}\right)$ & $0.6^{\mathrm{a}}$ & $2.3^{b}$ & $2.6^{\mathrm{c}}$ & $2.4^{b c}$ & $* * *$ & $1.0^{\mathrm{a}}$ & $3.0^{\mathrm{b}}$ & $3.1^{b}$ & $2.7^{\mathrm{b}}$ & $* * *$ \\
\hline Octanoic acid $\left(\mathrm{C}_{8: 0}\right)$ & $0.8^{\mathrm{a}}$ & $2.2^{b}$ & $2.6^{\mathrm{c}}$ & $2.2^{b}$ & $* * *$ & $0.9^{\mathrm{a}}$ & $2.7^{\mathrm{b}}$ & $2.6^{\mathrm{b}}$ & $2.3^{b}$ & $* * *$ \\
\hline Capric acid $\left(\mathrm{C}_{10: 0}\right)$ & $1.8^{\mathrm{a}}$ & $4.3^{b}$ & $6.2^{\mathrm{c}}$ & $5.0^{\mathrm{b}}$ & $* * *$ & $1.9^{\mathrm{a}}$ & $7.9^{b}$ & $9.1^{\mathrm{c}}$ & $8.6^{b c}$ & $* * *$ \\
\hline Lauric acid $\left(\mathrm{C}_{12: 0}\right)$ & $2.6^{\mathrm{a}}$ & $6.5^{b}$ & $10.7^{\mathrm{c}}$ & $7.8^{b}$ & $* * *$ & $3.0^{\mathrm{a}}$ & $12.7^{\mathrm{b}}$ & $14.6^{\mathrm{c}}$ & $13.7 \mathrm{bc}$ & $* * *$ \\
\hline Myristic acid $\left(\mathrm{C}_{14: 0}\right)$ & $6.3^{\mathrm{a}}$ & $18.5^{\mathrm{b}}$ & $35.7^{\mathrm{c}}$ & $23.2^{\mathrm{b}}$ & $* * *$ & $7.3^{\mathrm{a}}$ & $39.5^{\mathrm{b}}$ & $47.1^{\mathrm{c}}$ & $40.6^{\mathrm{b}}$ & $* * *$ \\
\hline Myristoleic acid $\left(\mathrm{C}_{14: 1}\right)$ & $0.7^{\mathrm{a}}$ & $1.7^{\mathrm{b}}$ & $2.6^{\mathrm{c}}$ & $1.9^{\mathrm{b}}$ & $* * *$ & $0.9^{\mathrm{a}}$ & $2.8^{\mathrm{b}}$ & $2.9^{b}$ & $2.8^{b}$ & $* * *$ \\
\hline Pentadecanoic acid $\left(\mathrm{C}_{15: 0}\right)$ & $1.0^{\mathrm{a}}$ & $3.3^{b}$ & $6.2^{\mathrm{c}}$ & $3.7^{\mathrm{b}}$ & $* * *$ & $1.1^{\mathrm{a}}$ & $6.7^{b}$ & $8.4^{\mathrm{c}}$ & $7.3^{b}$ & $* * *$ \\
\hline Palmitic acid $\left(\mathrm{C}_{16: 0}\right)$ & $19.9^{\mathrm{a}}$ & $64.0^{\mathrm{b}}$ & $130.0^{\mathrm{d}}$ & $84.4^{\mathrm{c}}$ & $* * *$ & $21.9^{\mathrm{a}}$ & $133.3^{\mathrm{b}}$ & $177.6^{c}$ & $147.6^{b}$ & $* * *$ \\
\hline Palmitoleic acid $\left(\mathrm{C}_{16: 1}\right)$ & $2.4^{\mathrm{a}}$ & $5.4^{\mathrm{b}}$ & $8.9^{\mathrm{c}}$ & $6.5^{b}$ & $* * *$ & $2.9^{\mathrm{a}}$ & $11.8^{\mathrm{b}}$ & $11.1^{\mathrm{b}}$ & $16.5^{\mathrm{c}}$ & $* * *$ \\
\hline Stearic acid $\left(\mathrm{C}_{18: 0}\right)$ & $6.8^{\mathrm{a}}$ & $15.6^{\mathrm{b}}$ & $29.1^{\mathrm{c}}$ & $19.8^{\mathrm{b}}$ & $* * *$ & $6.9^{\mathrm{a}}$ & $30.3^{\mathrm{b}}$ & $40.9^{\mathrm{c}}$ & $39.1 \mathrm{bc}$ & $* * *$ \\
\hline Oleic acid $\left(\mathrm{C}_{18: 1}\right)$ & $18.3^{\mathrm{a}}$ & $47.5^{b}$ & $68.9^{\mathrm{c}}$ & $52.2^{b}$ & $* * *$ & $23.6^{\mathrm{a}}$ & $68.3^{\mathrm{b}}$ & $71.0^{\mathrm{b}}$ & $70.4^{\mathrm{b}}$ & $* * *$ \\
\hline Linoleic acid $\left(\mathrm{C}_{18: 2}\right)$ & $2.5^{\mathrm{a}}$ & $6.4^{\mathrm{b}}$ & $10.1^{\mathrm{b}}$ & $6.5^{\mathrm{b}}$ & $* * *$ & $3.6^{\mathrm{a}}$ & $10.9^{b}$ & $14.6^{\mathrm{b}}$ & $14.1^{\mathrm{b}}$ & $* *$ \\
\hline Linolenic acid $\left(\mathrm{C}_{18: 3}\right)$ & $0.7^{\mathrm{a}}$ & $1.1^{\mathrm{ab}}$ & $1.9^{\mathrm{c}}$ & $1.3^{b}$ & $* * *$ & $1.0^{\mathrm{a}}$ & $1.8^{\mathrm{b}}$ & $1.6^{\mathrm{b}}$ & $1.3^{\mathrm{b}}$ & $* *$ \\
\hline Conjugated linoleic acid $\ddagger$ & $0.4^{\mathrm{a}}$ & $1.1^{b}$ & $1.4^{\mathrm{c}}$ & $1.1^{\mathrm{b}}$ & $* * *$ & $0.5^{\mathrm{a}}$ & $1.4^{\mathrm{b}}$ & $1.4^{\mathrm{b}}$ & $1.6^{\mathrm{b}}$ & $* * *$ \\
\hline Arachidic acid $\left(\mathrm{C}_{20: 0}\right)$ & 0.2 & 0.2 & 0.8 & 0.3 & NS & $0.2^{\mathrm{a}}$ & $0.4^{\mathrm{ab}}$ & $0.9^{\mathrm{b}}$ & $0.6^{\mathrm{ab}}$ & $*$ \\
\hline Gadoleic acid $\left(\mathrm{C}_{20: 1}\right)$ & $0.3^{\mathrm{a}}$ & $0.6^{\mathrm{b}}$ & $0.8^{\mathrm{c}}$ & $0.5^{\mathrm{b}}$ & $* * *$ & $0.4^{\mathrm{a}}$ & $0.7^{b}$ & $0.6^{\mathrm{b}}$ & $0.7^{b}$ & $* *$ \\
\hline Unsaturated FFA \# & $25.2^{\mathrm{a}}$ & $63.8^{b}$ & $94.5^{\mathrm{c}}$ & $70.0^{\mathrm{b}}$ & $* * *$ & $32.7^{\mathrm{b}} \mathrm{a}$ & $97.5^{b}$ & $103.1^{b}$ & $107.4^{b}$ & $* * *$ \\
\hline Saturated $\mathrm{C}_{4: 0}-\mathrm{C}_{8: 0}$ & $3.0^{\mathrm{a}}$ & $7.7^{b}$ & $8.8^{c}$ & $8.3^{b c}$ & $* * *$ & $4.5^{\mathrm{a}}$ & $10.8 \mathrm{bc}$ & $11.8^{\mathrm{c}}$ & $10.3^{b}$ & $* * *$ \\
\hline Saturated $C_{10: 0^{-}} \mathrm{C}_{20: 0}$ & $38.5^{\mathrm{a}}$ & $112.3^{b}$ & $218.7^{c}$ & $144.1^{b}$ & $* * *$ & $42.3^{\mathrm{a}}$ & $230.8^{b}$ & $298.5^{c}$ & $257.4^{b}$ & $* * *$ \\
\hline Total free fatty acids & $66.7^{\mathrm{a}}$ & $183.8^{\mathrm{b}}$ & $321.9^{\mathrm{c}}$ & $222.4^{\mathrm{b}}$ & $* * *$ & $79.5^{\mathrm{a}}$ & $339^{b}$ & $413.5^{\mathrm{c}}$ & $375.1^{b c}$ & $* * *$ \\
\hline
\end{tabular}

a All acids were analysed by GC, but acetic and propionic acids were analysed separately from the other acids, as described in the Materials and Methods section.

$\dagger: 2$ - and 3-methylbutanoic acids were calculated as follows: concentration of (2-methylbutanoic + 3-methylbutanoic acids) $\times$ proportion of each isomer of methylbutanoic acid. The proportions of acids were determined from the proportion of the corresponding methyl esters, which were synthesised and analysed as described in the Materials and Methods section.

$\mp$ : CLA constituted a mixture positional and geometric isomers of conjugated linoleic acid.

\#: Sum of $\mathrm{C}_{14: 1}, \mathrm{C}_{16: 1}, \mathrm{C}_{18: 1}, \mathrm{C}_{18: 2}$ including CLA, $\mathrm{C}_{18: 3}$, and $\mathrm{C}_{20: 1}$.

b Results are means of six experiments (averaged values across three lactic starters and duplicates). Values in the same row at the same ripening stage with the same superscript were not significantly different according to the LSD test $(\alpha<0.05)$.

${ }^{c}$ Ctrl: control cheese manufactured under the same conditions without $P$. freudenreichii.

d Probability of F-test: *** $P<0.001$; ** $0.001<P<0.01 ; * 0.01<P<0.05$; NS, $P>0.05$. 
Both acids were further produced during the cold storage, with values of $272 \pm 21.7$ and $721 \pm 27.8 \mathrm{mg} \cdot 100 \mathrm{~g}^{-1}$, respectively, in the presence of PAB and $66 \pm 16.0$ and $1 \pm$ $0.5 \mathrm{mg} \cdot 100 \mathrm{~g} \mathrm{~g}^{-1}$, respectively, in the control cheeses, at the end of ripening. These values are in the range of concentrations reported in Swiss cheese but the molar ratio of propionate and acetate that can be calculated from these concentrations was higher in the present study (2.2 in cheeses containing $\mathrm{PAB}$ ) than in previous reports $(0.5$ to 2.1$)$ [4, 7 , $23,25,34,39]$. From the concentrations observed in the present study in the control cheeses, manufactured in the absence of $\mathrm{PAB}$, it can be estimated that the total propionic acid and most $(75 \%)$ of the acetic acid produced resulted from PAB metabolism. Taking these data into account, the molar ratio of propionate and acetate produced by propionibacteria could be evaluated as 2.8 .

\subsection{Production of short branched- chain fatty acids}

Both 2-methylbutanoic acid and 3-methylbutanoic acid (also referred to as isovaleric acid) were produced in the cheeses. Using a simple esterification method, we showed that the peak formed by the co-elution of both isomers of methylbutanoic acids actually constituted 58 to $88 \%$ of 2-methylbutyric acid in cheeses containing PAB, and $35 \%$ in the control cheeses. 2-Methylbutyric acid was essentially produced by $\mathrm{PAB}$, with concentrations 12 to 50 times higher in cheeses containing PAB than in the control cheeses. Significant differences $(P<0.001)$ of 2-methylbutanoic acid production were observed between PAB strains, at both ripening stages (Tab. I), with strains ITGP14 and ITGP17 producing the highest and the lowest levels, respectively. The same classification of PAB strains was observed for the production of 3-methylbutanoic acid (Tab. I). These results confirm, using the same PAB strains but different lactic starters, previous observations in mini-Swiss cheeses which showed that 2-methyl/3-methylbutanoic acids were mainly produced by
PAB [46]. From the concentrations of methylbutanoic acids detected in the control cheeses, it could be estimated that thermophilic lactic starters directly contribute to the production of only $\sim 3 \%$ and $20 \%$ of the total levels of 2-methylbutanoic and 3methylbutanoic acids produced, respectively, in cheeses. Thermophilic lactic starters also had an indirect contribution to the formation of $\mathrm{BC}$ acids, by modulating the production of these acids by PAB. Hence, the concentrations observed in the presence of starter LH77 were significantly $(P<0.05,2$-methylbutanoic acid and $P<0.001,3$-methylbutanoic acid) higher than the ones observed for starter LH56-LL57 (Fig. 1). The main production of short BC acids $(59 \pm 14 \%$ and $61 \pm 13 \%$ of 2-methyl- and 3-methylbutanoic acid, respectively) occurred during the cold storage in all cheeses, as was previously observed [47]. Methylbutanoic acids impart a cheesy/sweaty note to cheese and are thought to play a role in cheese flavour [49, 51]. In Swiss cheese, 3-methylbutanoic acid was found to contribute to cheese taste, whereas 2-methyl-butanoic acid was not cited [34].

\subsection{Production of free fatty acids}

The concentrations of all the FFA derived from lipolysis were 2 to 8 times higher in the presence of $P$. freudenreichii, depending on the strain and the fatty acid considered (Tab. I). The strain P. freudenreichii ITGP23 produced the highest concentration of FFA throughout ripening (Tab. I, Fig. 1). Palmitic $\left(\mathrm{C}_{16: 0}\right)$, oleic $\left(\mathrm{C}_{18: 1}\right)$, myristic $\left(\mathrm{C}_{14: 0}\right)$ and stearic $\left(\mathrm{C}_{18: 0}\right)$ acids were the most abundant acids in all the cheeses, constituting $45-50 \%$ of FFA, as in milk fat [12]. This result indicates that FFA essentially arise from a non-specific hydrolysis of milk triglycerides, in agreement with previous results [26]. It should be noted, however, that the three PAB strains induced a greater release of medium-chain and long-chain saturated FFA $\left(\mathrm{C}_{14: 0}, \mathrm{C}_{15: 0}, \mathrm{C}_{16: 0}\right.$ and $\left.\mathrm{C}_{18: 0}\right)$. They were five- to eight-fold higher in the presence of $\mathrm{PAB}$ than in the control cheeses, 

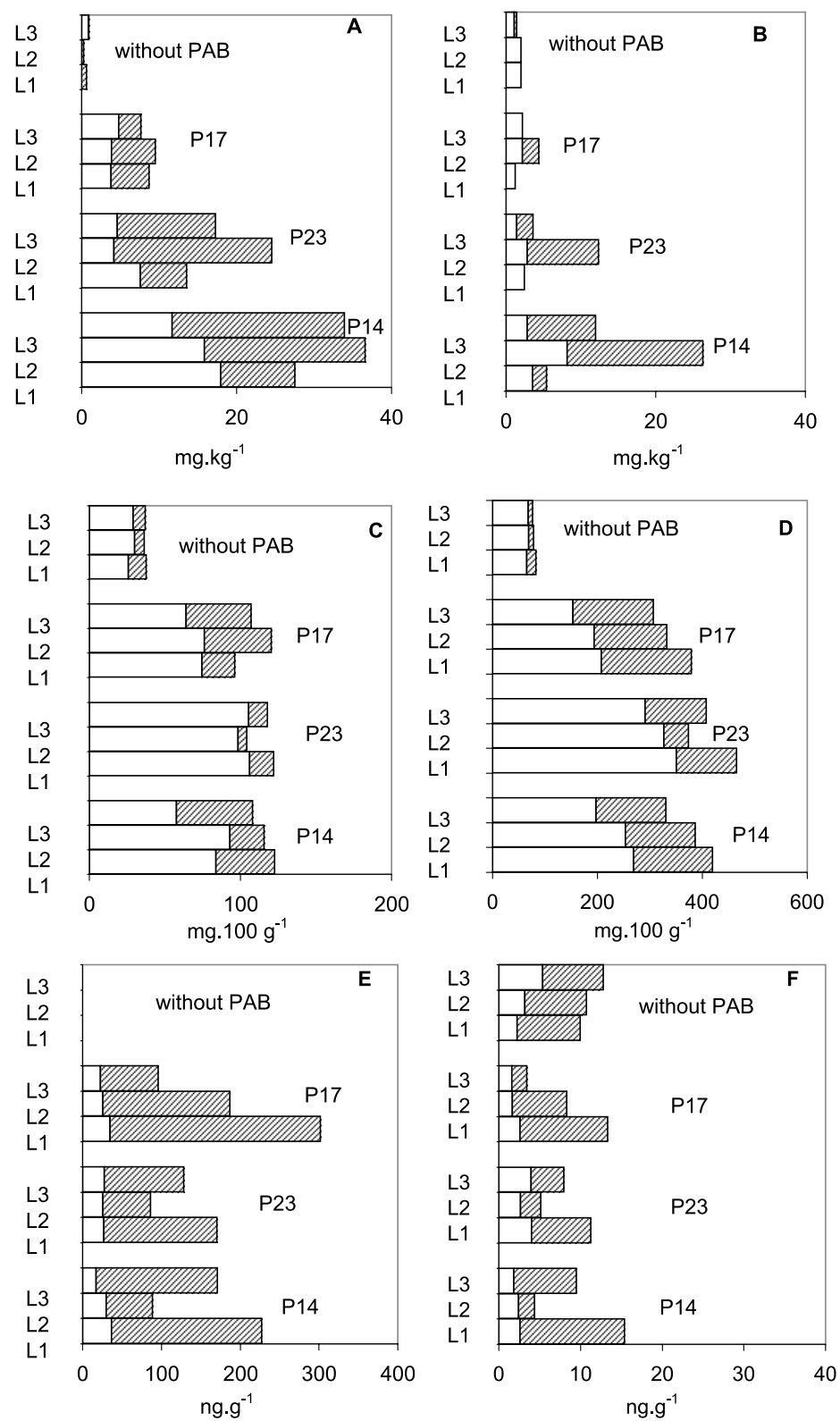

Figure 1. Production of volatile compounds in mini-Swiss cheeses made using different combinations of lactobacilli starters (L1, LH56-LL57; L2, LH77; L3, LH100) and propionibacteria (three strains of $P$. freudenreichii, ITGP17, ITGP23 and ITGP14, and a control cheese without PAB). Production of compounds is shown at the end of ripening in the warm room (open bars) and during a subsequent cold storage period for 8 weeks at $4{ }^{\circ} \mathrm{C}$ (hatched bars). Values are means of duplicate batches of cheeses. A, 2-methylbutanoic acid; B, 3-methylbutanoic acid; $C$, sum of short-chain $\left(\mathrm{C}_{4: 0^{-}}\right.$

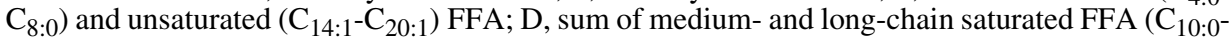
$\mathrm{C}_{20: 0}$ ); E, ethyl propionate; $\mathrm{F}$, ethyl butanoate. 
compared with the release of short-chain $\left(\mathrm{C}_{4: 0}, \mathrm{C}_{6: 0}\right.$ and $\left.\mathrm{C}_{8: 0}\right)$, and unsaturated FFA $\left(\mathrm{C}_{16: 1}, \mathrm{C}_{18: 1}, \mathrm{C}_{18: 2}\right.$ and $\left.\mathrm{C}_{18: 3}\right)$, which showed a two- to three-fold increase in the presence of PAB. From values observed in the control cheeses, it could be assumed that lactic starters produced $16 \%$ of saturated FFA, $32 \%$ of unsaturated FFA, and $41 \%$ of shortchain FFA of the total amounts found in the cheeses. This study in controlled-flora cheeses confirms the initial observations of Chamba et al. studying full-size Emmental cheeses, who showed that PAB lipolytic activity was the main factor of lipolysis in Swiss-type cheeses [10]. However, lactobacilli starters also had an indirect contribution to the formation of FFA, by modulating the effect of $\mathrm{PAB}$ on lipolysis. The concentrations of long-chain saturated FFA released, in particular, were significantly $(P<0.05)$ higher $(+31 \%)$ in the presence of lactobacilli strains LH56-LL57 than in the presence of lactobacilli strain LH100, as shown in Figure 1. This effect could be related to the time period in the warm room, which was $60 \%$ longer, on average, for cheeses made using LH56-LL57 than for cheeses made using LH100, as noted above. The greatest production of FFA was during the warm room ripening stage, but significant levels were still produced at $4{ }^{\circ} \mathrm{C}(41 \pm$ $13 \%, 25 \pm 4 \%$, and $25 \pm 15 \%$ of long-chain saturated FFA, short-chain FFA, and unsaturated FFA, respectively). Short- and medium-chain FFA are considered as important contributors to cheese flavour, even though levels of lipolysis of less than $1 \%$ have been reported in good quality Swiss cheeses $[10,34]$.

\subsection{Neutral volatile compounds}

Fifty-six neutral volatile compounds were identified in the cheeses by headspace GC-MS (Tabs. II and III). All compounds detected have previously been reported in Swiss-type cheeses $[8,29,43,45]$ except 3 heptanone, which has been reported in butter and in other cheese varieties such as
Parmesan [29]. The concentrations of twentythree volatiles were significantly influenced by the presence of PAB. Nine volatile compounds were detected at greater concentrations in the presence of each of the three PAB strains, and six compounds in the presence of one or two PAB strains (Tab. II). The main groups of neutral volatile compounds detected at a higher concentration in the presence of PAB than in the control cheeses were esters of propionate and some $\mathrm{BC}$ compounds. In contrast, eight compounds were detected at lower concentrations in the presence of PAB: two alcohols (2-butanol and 2-pentanol), three aldehydes (2-methylpropanal, 3-methylbutanal and pentanal), two ketones (2,3-butanedione and 2-heptanone) and dimethyl trisulphide (Tab. II).

Five of the sixteen esters detected in the cheese were more abundant in the presence of PAB: four esters of propionate, and propyl acetate (Tab. II). The presence of propionate esters, as expected, was strictly dependent on the presence in the cheese of propionic acid, i.e. of PAB. Ethyl propionate was by far the most abundant ester in mini-Swiss cheese, as previously reported in this type of mini-cheese [45]. The concentrations of ethyl propionate were similar with the three PAB strains, but were significantly $(P<0.05)$ influenced by the strains of lactobacilli, with the highest concentrations detected in cheeses manufactured using starter LH56-LL57 (Fig. 1). Similarly, two ethyl esters, ethyl hexanoate and ethyl heptanoate, were detected at significantly $(P<0.05)$ higher levels in the presence of starter LH56-LL57 than in the presence of starter LH77 (data not shown). All the identified esters were synthesised mainly during the cold storage of the cheese (70-81\% of the total amount produced), as shown for ethyl propionate and ethyl butanoate in Figure 1. The observation of similar kinetics of ester synthesis in the absence and in the presence of $\mathrm{PAB}$, as observed for ethyl butanoate synthesis, suggests that enzymes of lactic acid starters are involved in their synthesis. PAB are therefore not necessarily directly involved in the 
Table II. Effect of three strains of Propionibacterium freudenreichii (P17, P23 and P14) on the concentration of neutral volatile compounds in mini-Swiss cheeses.

\begin{tabular}{|c|c|c|c|c|c|c|c|c|c|c|c|c|}
\hline \multirow{2}{*}{$\frac{\mathrm{RT}^{\mathrm{a}}}{(\mathrm{min})}$} & \multirow[t]{2}{*}{ Compound $\left(n g \cdot g^{-1}\right)^{b}$} & \multirow[t]{2}{*}{$\mathrm{QI}^{\mathrm{c}}$} & \multicolumn{5}{|c|}{ At the end of warm room period ${ }^{d}$} & \multicolumn{5}{|c|}{ After two month's storage at $4{ }^{\circ} \mathrm{C}^{\mathrm{d}}$} \\
\hline & & & $\mathrm{Ctrl}^{\mathrm{e}}$ & $\mathrm{P} 17$ & P23 & P14 & stat ${ }^{f}$ & $\mathrm{Ctrl}{ }^{\mathrm{e}}$ & P17 & P23 & $\mathrm{P} 14$ & stat $^{\mathrm{f}}$ \\
\hline & alcohols & & & & & & & & & & & \\
\hline 7.92 & 2-Butanol & 45 & nd & nd & nd & nd & - & $11.8^{\mathrm{b}}$ & $4.0^{\mathrm{a}}$ & $4.9^{\mathrm{a}}$ & $3.3^{\mathrm{a}}$ & $* * *$ \\
\hline 11.90 & 2-Pentanol & 45 & $3.9^{b}$ & $0.6^{\mathrm{a}}$ & $0.8^{\mathrm{a}}$ & $0.7^{\mathrm{a}}$ & $*$ & $23.3^{b}$ & $0.6^{\mathrm{a}}$ & $5.0^{\mathrm{a}}$ & $0.1^{\mathrm{a}}$ & $*$ \\
\hline 13.63 & 3-Methylbutanol $\dagger$ & 70 & $26.5^{\mathrm{a}}$ & $31.5^{\mathrm{a}}$ & $24.2^{\mathrm{a}}$ & $64.0^{\mathrm{b}}$ & $* *$ & 99.6 & 50.5 & 61.6 & 83.2 & NS \\
\hline 13.75 & $\begin{array}{l}\text { 2-Methylbutanol } \\
\text { aldehydes }\end{array}$ & 57 & $3.4^{\mathrm{a}}$ & $70.2^{b}$ & $77.6^{b}$ & $319.1^{\mathrm{c}}$ & $* * *$ & $11.7^{\mathrm{a}}$ & $126.0^{\mathrm{c}}$ & $77.9^{b}$ & $312.1^{\mathrm{d}}$ & $* * *$ \\
\hline 6.29 & 2-Methylpropanal & 72 & 1.6 & 0.9 & 1.3 & 1.3 & NS & $4.7^{b}$ & $1.3^{\mathrm{a}}$ & $1.8^{\mathrm{a}}$ & $2.6^{\mathrm{a}}$ & $* *$ \\
\hline 10.00 & 3-Methylbutanal $\dagger$ & TIC & $8.5^{b}$ & $2.2^{\mathrm{a}}$ & $3.1^{\mathrm{a}}$ & $4.5^{\mathrm{a}}$ & $* * *$ & $8.2^{b}$ & $2.9^{\mathrm{a}}$ & $3.2^{\mathrm{a}}$ & $4.0^{\mathrm{a}}$ & $* *$ \\
\hline 10.42 & 2-Methylbutanal & TIC & $2.7^{\mathrm{a}}$ & $17.3^{b}$ & $18.4^{\mathrm{b}}$ & $51.7^{\mathrm{c}}$ & $* * *$ & $3.0^{\mathrm{a}}$ & $14.6^{\mathrm{b}}$ & $15.5^{b}$ & $29.2^{\mathrm{c}}$ & $* *$ \\
\hline 11.84 & $\begin{array}{l}\text { Pentanal \# } \\
\text { esters }\end{array}$ & 44 & $2.1^{b}$ & $1.2^{\mathrm{a}}$ & $1.0^{\mathrm{a}}$ & $1.1^{\mathrm{a}}$ & $* *$ & $2.5^{b}$ & $1.2^{\mathrm{a}}$ & $1.5^{\mathrm{a}}$ & $1.2^{\mathrm{a}}$ & $*$ \\
\hline 9.02 & Methyl propionate \# & 88 & $0.0^{\mathrm{a}}$ & $3.7^{b}$ & $3.0^{\mathrm{b}}$ & $3.8^{b}$ & $* * *$ & $0.0^{\mathrm{a}}$ & $15.7^{b}$ & $14.0^{\mathrm{b}}$ & $15.7^{b}$ & $* * *$ \\
\hline 12.51 & Ethyl propionate $\dagger$ & TIC & $0.0^{\mathrm{a}}$ & $27.6^{b}$ & $25.3^{b}$ & $27.5^{b}$ & $* * *$ & $0.3^{\mathrm{a}}$ & $195.5^{b}$ & $128.9^{b}$ & $158.9^{b}$ & $* * *$ \\
\hline 12.64 & n-Propyl acetate & 43 & 0.2 & 0.4 & 0.9 & 0.3 & NS & $0.2^{\mathrm{a}}$ & $1.6^{\mathrm{b}}$ & $0.7^{\mathrm{a}}$ & $0.4^{\mathrm{a}}$ & $*$ \\
\hline 14.40 & Isopropyl propionate \# & 75 & nd & nd & nd & nd & - & $0.0^{\mathrm{a}}$ & $0.4^{\mathrm{a}}$ & $0.7^{b}$ & $0.4^{\mathrm{a}}$ & $*$ \\
\hline 16.79 & Propyl propionate & 57 & 0.02 & 0.05 & 0.01 & 0.06 & NS & $0.0^{\mathrm{a}}$ & $1.0^{\mathrm{b}}$ & $1.4^{\mathrm{b}}$ & $1.8^{\mathrm{b}}$ & $* *$ \\
\hline & ketones & & & & & & & & & & & \\
\hline 7.29 & 2,3-Butanedione $\dagger$ & 86 & 387 & 197 & 216 & 226 & NS & $494^{b}$ & $181^{\mathrm{a}}$ & $284^{\mathrm{a}}$ & $227^{\mathrm{a}}$ & $* *$ \\
\hline 7.60 & 2-Butanone & 72 & $195^{\mathrm{a}}$ & $278^{a}$ & $293^{a}$ & $429^{b}$ & $*$ & $305^{\mathrm{a}}$ & $411^{\mathrm{a}}$ & $376^{\mathrm{a}}$ & $574^{\mathrm{b}}$ & $*$ \\
\hline 11.74 & 2,3-Pentanedione \# & 100 & $1.9^{\mathrm{a}}$ & $12.1^{\mathrm{b}}$ & $8.0^{\mathrm{ab}}$ & $10.3^{b}$ & $*$ & $3.3^{\mathrm{a}}$ & $13.5^{b}$ & $14.6^{\mathrm{b}}$ & $10.6^{\mathrm{b}}$ & $* *$ \\
\hline 13.77 & 4-Methyl-2-pentanone & 43 & $1.5^{\mathrm{a}}$ & $1.8^{\mathrm{a}}$ & $2.3^{\mathrm{a}}$ & $5.0^{\mathrm{b}}$ & $* * *$ & $2.1^{\mathrm{a}}$ & $3.3^{\mathrm{a}}$ & $3.5^{\mathrm{ab}}$ & $5.0^{\mathrm{b}}$ & $* *$ \\
\hline 15.95 & 2-Hexanone & TIC & $3.4^{\mathrm{a}}$ & $9.9^{\mathrm{ab}}$ & $6.1^{\mathrm{a}}$ & $13.3^{b}$ & $*$ & 8.6 & 12.6 & 8.8 & 9.8 & NS \\
\hline 20.14 & 2-Heptanone $\dagger$ & TIC & 142.7 & 104.6 & 105.6 & 105.8 & NS & $235.2^{b}$ & $111.1^{\mathrm{a}}$ & $138.8^{a}$ & $124.3^{\mathrm{a}}$ & $*$ \\
\hline 22.53 & 6-Methyl-2-heptanone \# & 58 & 0.0 & 0.1 & 0.1 & 0.1 & NS & $0.0^{\mathrm{a}}$ & $0.4^{b}$ & $0.5^{b}$ & $0.6^{b}$ & $* * *$ \\
\hline 23.01 & 5-Methyl-2-heptanone \# & 43. 58 & $0.0^{\mathrm{a}}$ & $1.0^{b c}$ & $1.4^{\mathrm{c}}$ & $0.7^{b}$ & $* *$ & $0.0^{\mathrm{a}}$ & $0.8^{b}$ & $1.0^{\mathrm{b}}$ & $0.7^{b}$ & $* * *$ \\
\hline 23.95 & 2-Octanone \# & 58 & 1.7 & 3.2 & 2.2 & 5.2 & NS & $2.4^{\mathrm{a}}$ & $4.2^{b}$ & $2.5^{\mathrm{ab}}$ & $4.4^{b}$ & $*$ \\
\hline & S-containing compound & & & & & & & & & & & \\
\hline 23.65 & Dimethyl trisulphide & 126 & $1.1^{\mathrm{b}}$ & $0.3^{\mathrm{a}}$ & $0.5^{\mathrm{a}}$ & $0.4^{\mathrm{a}}$ & $*$ & 0.5 & 0.3 & 0.4 & 0.6 & NS \\
\hline
\end{tabular}

${ }^{\mathrm{a}} \mathrm{RT}$, retention time in GC-MS.

b Values are concentrations expressed in ng. $\mathrm{g}^{-1}$. Five compounds, marked with $\dagger$, were quantified by a regression curve obtained using authentic standards, and the other compounds quantified using the regression curve of a closely related standard, as described in Materials and Methods. Compounds marked with \# were tentatively identified by comparison of mass spectral data with those of the NIST 75K database.

${ }^{\mathrm{c}} \mathrm{QI}$, quantification ions: TIC, total ion current peak areas were used or selected fragment(s) as indicated.

${ }^{\mathrm{d}}$ Results are means of six experiments (averaged values across three lactic starters and duplicates). nd, not detected. Values in the same row at the same ripening stage with the same superscript were not significantly different according to the LSD test $(\alpha<0.05)$.

e Ctrl: control cheese manufactured under the same conditions without $P$. freudenreichii.

f Probability of F-test: *** $P<0.001 ; * * 0.001<P<0.01 ; * 0.01<P<0.05 ;$ NS, $P>0.05$. 
Table III. Neutral volatile compounds of mini-Swiss cheeses whose levels were not affected by the presence of Propionibacterium freudenreichii.

\begin{tabular}{|c|c|c|c|c|c|}
\hline $\mathrm{RT}^{\mathrm{a}}(\min )$ & Compound ${ }^{b}$ & $\mathrm{QI}^{\mathrm{c}}$ & $\mathrm{RT}^{\mathrm{a}}(\min )$ & Compound ${ }^{b}$ & $\mathrm{QI}^{\mathrm{c}}$ \\
\hline \multicolumn{6}{|l|}{ alcohols } \\
\hline 4.30 & Ethanol & 45 & aldehydes & & \\
\hline 4.90 & 2-Propanol & 45 & 16.40 & Hexanal \# & 56 \\
\hline 6.29 & 1-Propanol & 31 & 20.58 & Heptanal & 44 \\
\hline 9.02 & 2-Methyl-1-propanol & TIC & 24.40 & Octanal & $84(\operatorname{tr})$ \\
\hline 10.45 & 1-Butanol \# & 41 & 27.68 & Nonanal \# & 57 \\
\hline 13.35 & 3-Methyl-3-butenol & 56 & & & \\
\hline 14.96 & 1-Pentanol & 55 & ketones & & \\
\hline 20.40 & 2-Heptanol \# & 83 & 10.21 & 3-Methyl-2-butanone \# & TIC (tr) \\
\hline esters & & & 11.27 & 2-Pentanone & TIC \\
\hline 5.46 & Methyl acetate & TIC (tr) & 14.40 & 3-Methyl-2-pentanone & $72(\mathrm{e}, \mathrm{tr})$ \\
\hline 8.33 & Ethyl acetate & 61 & 15.83 & 3-Hexanone \# & 57 \\
\hline 13.06 & Methyl butanoate & $74(\mathrm{e}, \mathrm{tr})$ & 19.96 & 3-Heptanone \# & $57(\operatorname{tr})$ \\
\hline 16.40 & Ethyl butanoate & 88 & 23.81 & 6-Methyl-5-hepten-2-one \# & TIC (tr) \\
\hline 17.021 & Butyl acetate \# & 61 & 27.09 & 8-Nonen-2-one \# & $82(\mathrm{e})$ \\
\hline 18125 & Isopropyl butanoate \# & $71(\mathrm{e})$ & 27.33 & 2-Nonanone \# & TIC \\
\hline 21.37 & Methyl hexanoate \# & 87 (tr) & & & \\
\hline 23.00 & 3-Methylbutyl propionate ${ }^{\mathrm{d}}$ & 57 (tr) & others & & \\
\hline 23.98 & Ethyl hexanoate & 88 & 14.12 & Dimethyl disulphide & TIC \\
\hline 27.27 & Ethyl heptanoate \# & $88(\mathrm{e})$ & 24.12 & Pentamethyl heptane \# & 57 \\
\hline 29.60 & Ethyl octanoate \# & 88 (tr) & & & \\
\hline
\end{tabular}

a RT, retention time in GC-MS.

$\mathrm{b}$ Compounds marked with \# were tentatively identified by comparison of mass spectral data with those of the NIST $75 \mathrm{~K}$ database.

${ }^{\mathrm{c}}$ QI, quantification ions: TIC, total ion current peak areas were used or selected fragment(s) as indicated. tr, traces; e, detected only at the end of ripening (after the cold storage for two months).

d 3-methylbutyl or 2-methylbutyl propionate.

synthesis of esters of propionate, but may only act as providers of the acid moiety (as propionic acid or propionyl CoA). Esters are common volatile compounds in cheese, but their mechanism of synthesis in cheese is still largely unknown [28]. Esters are responsible for fruity flavours that can be considered as a flavour defect or contribute positively to cheese flavour [28]. In Swiss cheese, esters are though to contribute to the fruity note [33, 34], and their presence has also been associated with the sweet odour of this cheese [27].

Numerous BC compounds were detected at a higher concentration in cheeses made using PAB than in the controls (Tab. II). They include products from the catabolism of isoleucine (2-methylbutanol and 2-methylbutanal) and three BC ketones. PAB were the main producers of isoleucine-derived products. Control cheeses without PAB contained only $10-20 \%$ and $4-15 \%$, respectively, 
of the amounts of 2-methylbutanol and 2methylbutanal found in cheeses containing $\mathrm{PAB}$, irrespective of the lactic starter used. It should be noted that products of leucine catabolism (3-methylbutanol and 3-methylbutanal) reflected different patterns from products of isoleucine catabolism. Concentrations of 3-methylbutanol in cheeses containing $\mathrm{PAB}$ did not significantly differ by the end of ripening from the controls, whereas levels of 3-methylbutanal detected were lower in cheeses containing PAB.

Significant differences $(P<0.01)$ in the production of $\mathrm{BC}$ compounds were observed between $\mathrm{PAB}$ strains, at both ripening stages (Tab. II). Strain ITGP14 produced the highest concentrations of 3-methylbutanol and 2-methylbutanal, as noted above for the production of $\mathrm{BC}$ acids. This strain also produced two BC ketones, 4-methyl-2pentanone and 5-methyl-2-heptanone. The origin of BC ketones has not, to the authors' knowledge, been investigated, but these ketones have already been related to the presence of PAB [45]. The fact that their levels have been correlated with those of some other $\mathrm{BC}$ compounds suggests that $\mathrm{BC}$ ketones could also originate from $\mathrm{BC}$ amino acid catabolism.

Thermophilic lactobacilli contributed only slightly to the direct production of products originating from isoleucine catabolism. However, they significantly $(P<$ 0.05 ) influenced the production of 2-methylbutanol by PAB, which was $20 \%$ higher in cheeses made using starter LH77 than in cheeses made using both other lactic starters (data not shown). This stimulation of the production by this strain of lactobacilli had been observed above for the production of BC acids (Fig. 1). The mechanisms by which lactobacilli influenced the production of $\mathrm{BC}$ compounds by $\mathrm{PAB}$ have not been elucidated. Thermophilic lactobacilli are known to play a main role in the release of peptides and free amino acids in Swiss cheese, through the activity of their numerous aminopeptidases [11], and this activity is enhanced by cell lysis [50]. They are also capable of converting amino acids into various $\mathrm{BC}$ volatile compounds in vitro, and in particular catalyse transamination reaction, which is the first step of amino acid catabolism in cheese $[17,22,51]$. Therefore, the stimulatory effect that LH77 exerted on the synthesis of $\mathrm{BC}$ volatile compounds by $\mathrm{PAB}$ may have been due to its contribution to the release of $\mathrm{BC}$ precursors of volatile compounds, which may be amino acids or keto acids resulting from transamination. However, as neither proteolysis, nor lactobacilli lysis, nor enzymic activities were determined in this study, no conclusion can be drawn on this point.

$\mathrm{BC}$ alcohols and aldehydes constituted only minute amounts of the total amounts of BC compounds detected $(\sim 1 \%$ and $0.1 \%$, respectively, the remainder being $\mathrm{BC}$ acids). As both $\mathrm{BC}$ alcohols and $\mathrm{BC}$ aldehydes can be converted to their corresponding $\mathrm{BC}$ acids by cheese bacteria $[44,51]$, they probably constitute only transitory compounds in Swiss cheese. BC aldehydes are characterised by their malty flavour, and 3-methylbutanal is considered as an odorant in Swiss cheese [33, 34]. BC alcohols, like other alcohols identified in cheese, are believed not to have a direct influence on cheese flavour [26]. They can, however, be indirectly involved as precursors in ester formation. Only trace amounts of esters derived from $\mathrm{BC}$ alcohols were detected in the present study, but BC esters have been previously reported in Swiss-type cheeses $[8,29,45]$. In particular, the presence of BC esters of 2-methylbutanol and 3-methylbutanol (2-methyl and 3-methyl acetate, 2-methyl and 3-methyl propionate) was previously reported in mini-cheeses made using $\mathrm{PAB}$ strain ITGP22, although the concentrations of acids and $\mathrm{BC}$ alcohols were very similar in this study and the present study [45]. This result suggests that some $\mathrm{PAB}$ could have original abilities to synthesise BC compounds, and that these abilities are straindependent.

Thirty-three other neutral volatile compounds were identified in the cheeses, but 


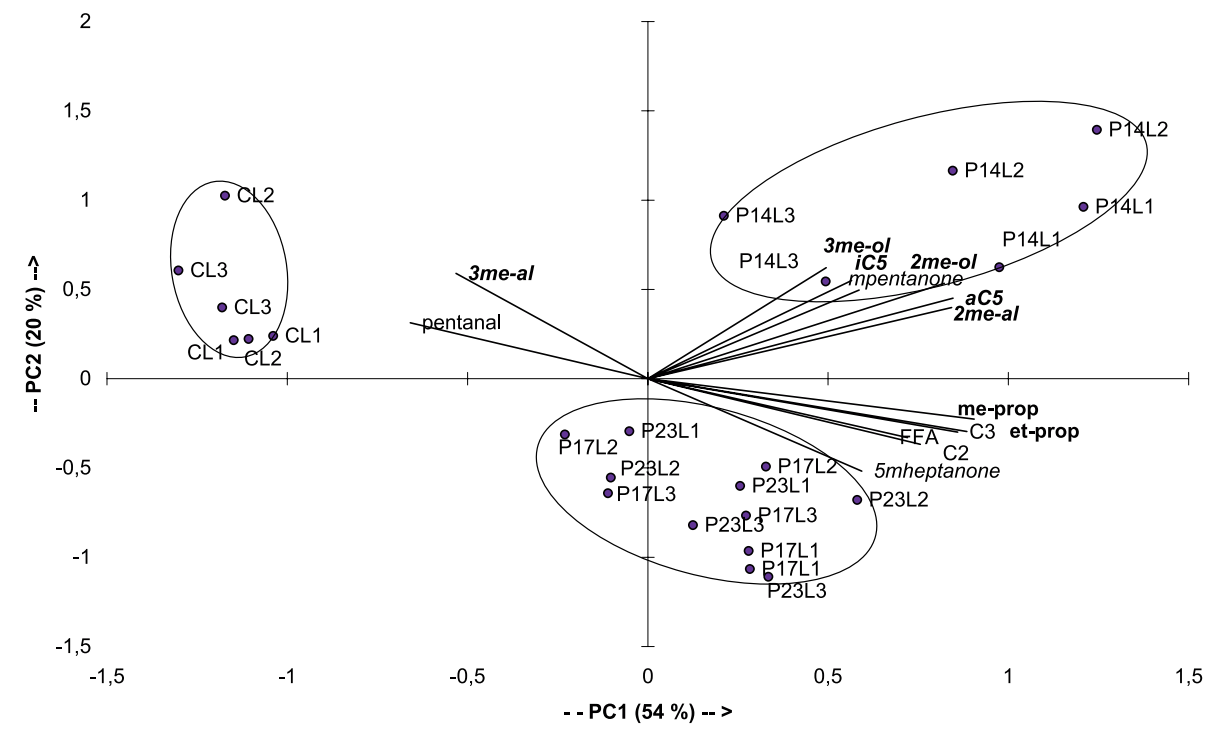

Figure 2. Results of principal component analysis on the volatile profile of mini-cheeses at the end of the ripening in the warm room. Biplot of PCA loading and scores for the first two principal components (PCs). Cheeses codes describe the different combinations of lactobacilli starters (L1, LH56LL57; L2, LH77; L3, LH100) and propionibacteria (three strains of $P$. freudenreichii, P17, P23 and P14 and C, control cheese without PAB). Variables: C2, acetic acid; C3, propionic acid; FFA, free fatty acids; iC5, 3-methylbutanoic acid; $\boldsymbol{a C 5}$, 2-methylbutanoic acid; 3me-ol, 3-methylbutanol; 3me$\boldsymbol{a l}$, 3-methylbutanal; 2me-ol, 2-methylbutanol; 2me-al, 2-methylbutanal; me-prop, methyl propionate; et-prop, ethyl propionate; mpentanone, 4-methyl-2-pentanone; 5mheptanone, 5-methyl-2heptanone, pentanal.

their concentrations were not significantly influenced by the presence of PAB or by the lactic starter used (except for the two ethyl esters mentioned above, ethyl hexanoate and ethyl heptanoate). These compounds include most alcohols, most aldehydes (except the BC ones), several ketones and the esters, not including those of propionate (Tab. III).

\subsection{Global fingerprint of propionibacteria}

The factors responsible for the similarities and the differences between cheese profiles of volatile compounds were identified by Principal Component Analysis (PCA). PCA was performed on the concentrations of the compounds listed in Tables I and II that ANOVA found significantly $(P<0.01)$ discriminated between the cheeses. As the data for individual FFA were highly correlated, only the sum of FFA was included in the data set for the first two PCA performed (Figs. 2 and 3). In the case of the third PCA, the sum of FFA, the sum of short-chain FFA $\left(\mathrm{C}_{4: 0}\right.$ to $\left.\mathrm{C}_{12: 0}\right)$, and the sum of long-chain FFA (from $C_{14: 0}$ to $C_{20: 1}$ ) were included in the data set (Fig. 4). PCA was performed on data obtained at the end of the warm period room and at the end of cold storage, and the first two components (PC1 and PC2) are represented graphically in Figure 2 and Figure 3 , respectively. A cumulative variation of $74 \%$ and $61 \%$, respectively, were explained by the first two PCs at each of these two stages. In both PCAs performed, PC1 separated the control cheeses from those containing $\mathrm{PAB}$, and accounted for $54 \%$ and $49 \%$ of the variation, respectively, 


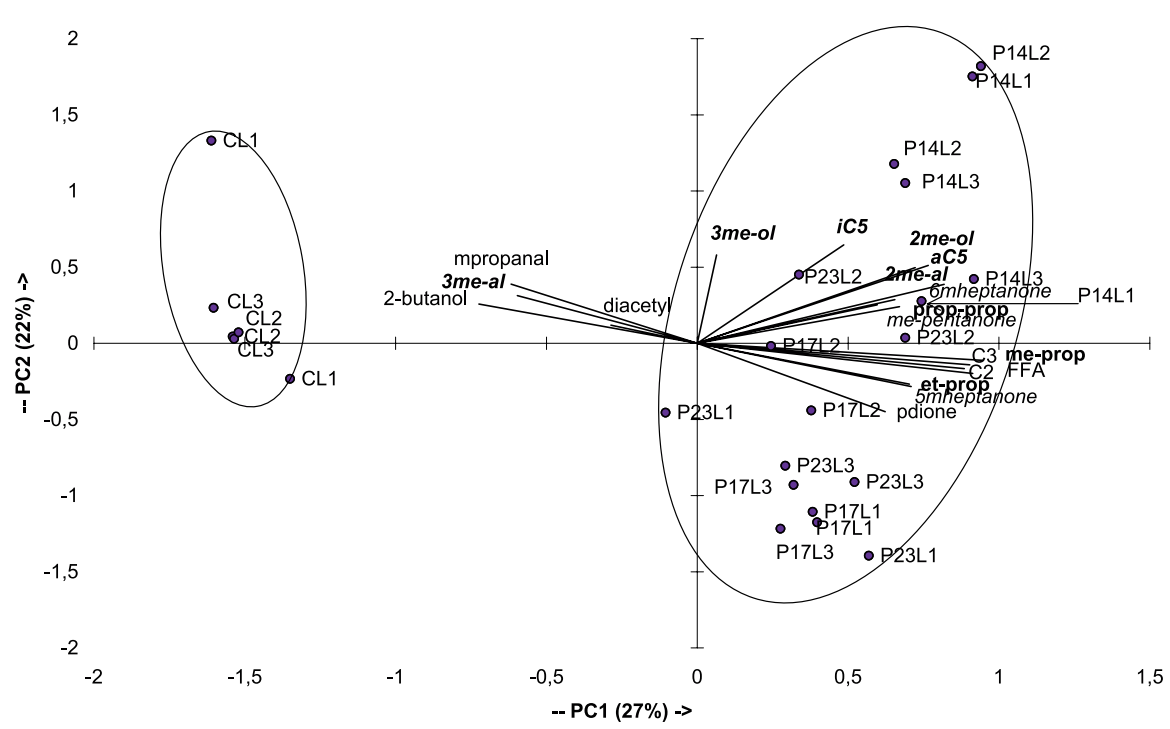

Figure 3. Results of principal component analysis on the volatile profile of mini-cheeses at the end of cold storage. Biplot of PCA loading and scores for the first two principal components (PCs). Cheeses codes: see Figure 2. Variables: see Figure 2 legend and: mpropanal, 2-methylpropanal; propprop, propyl propionate; 6mheptanone, 6-methyl-2-heptanone; 2-butanol; acetone (2-propanone); diacetyl, 2,3-butanedione; pdione, 2,3-pentanedione.

in PCA performed at each of the two stages of ripening (Figs. 2 and 3 ). Cheeses containing $\mathrm{PAB}$ were characterised by high levels of propionic acid, acetic acid, esters of propionic acid, FFA, and most BC compounds, in particular those arising from isoleucine catabolism (2-methylbutanoic acid, 2-methylbutanol and 2-methylbutanal) (Fig. 2). At the end of ripening, additional compounds, such as BC ketones (4-methyl-2-pentanone, 6-methyl-2-heptanone and 5-methyl-2-heptanone), 2,3-pentanedione, and propyl propionate also associated positively with $\mathrm{PC} 1$ (Fig. 3). PC2 differentiated cheeses made using strain ITGP14 from the cheeses made using the other two PAB strains, and accounted for $20 \%$ and $12 \%$ of the variation, in the PCA performed on data at the end of the warm room period and at the end of cold storage, respectively. Cheeses made using ITGP14 were characterised on PC2 by a high content of most $\mathrm{BC}$ compounds, in particular products derived from leucine catabolism (3-methylbutanoic acid and 3- methylbutanol). To emphasise the differences between cheeses containing PAB, a third PCA was performed by excluding the data obtained for control cheeses. The first two PCs accounted for $49 \%$ of the experimental variance obtained. PC1, representing $27 \%$ of the variation, separated the cheeses made using starter LH56-LL57 from the cheeses made using the other two lactic starters. Cheeses manufactured using starter LH56-LL57 were characterised on PC1 by a high content of FFA and ethyl propionate. PC2, representing $22 \%$ of the variation, separated the cheeses made using ITGP14 from the cheeses made using the other two PAB strains on the basis of their content in $\mathrm{BC}$ compounds originating from isoleucine catabolism (Fig. 4).

\section{CONCLUSIONS}

The presence of PAB in cheese resulted in an increase in a variety of products which originate from various sources, such as fermentation of lactic acid, lipolysis, BC 


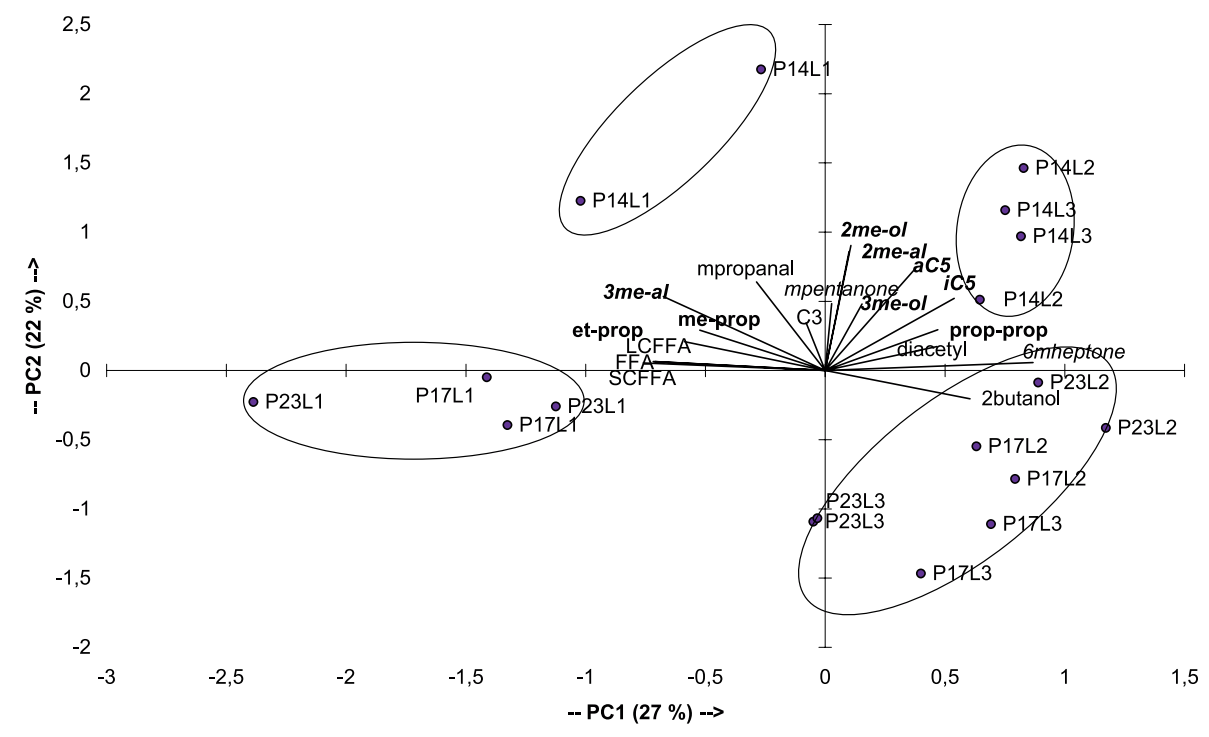

Figure 4. Results of principal component analysis on the volatile profile of mini-cheeses containing propionibacteria, at the end of cold storage. Biplot of PCA loading and scores for the first two principal components (PCs). Cheeses codes: see Figure 2 (control cheeses without PAB not included). Variables: see Figure 2 and 3 legends and SCFFA, short-chain FFA; LCFFA, long-chain FFA.

amino acid catabolism and other pathways. These results confirmed previous results obtained in mini-cheeses made using another $\mathrm{PAB}$ strain [45]. BC compounds originating from isoleucine catabolism (2-methylbutanoic acid, 2-methylbutanol and 2-methylbutanal) were detected in higher concentrations than the corresponding products originating from leucine catabolism in the presence of PAB, whereas the opposite was observed in the control cheeses. The presence of high levels of 2-methyl-branched-chain compounds appears as a characteristic feature of Swiss-type cheeses, in comparison with other internal bacterially ripened cheese varieties, as previously suggested $[25,41]$.

PAB produced volatile compounds in the cheeses both during their growth at $24{ }^{\circ} \mathrm{C}$ and during the subsequent cold storage period at $4{ }^{\circ} \mathrm{C}$. The proportions of volatile compounds produced during the warm and cold storage periods, respectively, greatly differed depending on their origin. Hence, $\sim 20 \%$ of propionic and acetic acids, $\sim 25 \%$ of short-chain and $41 \%$ of long-chain FFA derived from lipolysis, $60 \%$ of BC acids originating from isoleucine/leucine catabolism, and $\sim 80 \%$ of esters were produced during the cold storage period. These results are in agreement with previous studies in full-size Emmental cheese, which showed that esters were the compounds showing the largest increase $(\times 5-7)$ from 3 to 12 months of ripening, followed by 2-heptanone (fivefold increase) and short-chain FFA (two- to three-fold increase) [39].

This study clearly shows that the concentrations of volatile compounds produced by $P$. freudenreichii originating from lipolysis and BC amino acid catabolism are straindependent. Several of these volatiles could play a role in the formation of cheese flavour. Sensory evaluation now has to be performed to find out if the flavour profiles of the cheeses are perceived as different, and in which attributes they differ. 
Acknowledgements: This work was supported by funds provided by the Brittany Region. We are grateful to Dr. J.A. Hannon for critical reviewing of the manuscript, and we thank G. Roset and L. Aubert for skilled cheese manufacture.

\section{REFERENCES}

[1] Ayad E.H.E., Verheul A., Engels W.J.M., Wouters J.T.M., Smit G., Enhanced flavour formation by combination of selected lactococci from industrial and artisanal origin with focus on completion of a metabolic pathway, J. Appl. Microbiol. 90 (2001) 59-67.

[2] Baer A., Ryba I., Interactions between propionic acid bacteria and themophilic lactic acid bacteria, Lait 79 (1999) 79-92.

[3] Beck H.C., Hansen A.M., Lauritsen F.R., Metabolite production and kinetics of branched-chain aldehyde oxidation in Staphylococcus xylosus, Enz. Microb. Technol. 31 (2002) 94-101.

[4] Berdagué J.L., Grappin R., DelacroixBuchet A., Chaillet B., Caractérisation de l'emmental «Grand-Cru » français. I. Composition physico-chimique, Lait 70 (1990) $1-14$.

[5] Beresford T.P., Fitzsimons N.A., Brennan N.L., Cogan T.M., Recent advances in cheese microbiology, Int. Dairy J. 11 (2001) 253-274.

[6] Bergère J.L., Accolas J.P., Non-sporing and sporing anaerobes in dairy products, in: Barnes E.M., Mead G.C. (Eds.), Anaerobic bacteria in habitats other than man, Blackwell Scientific Publications, London, UK, 1986, pp. 373-395.

[7] Bosset J.O., Collomb M., Grand M., Lavanchy P., Kaufmann E., Kreuter U., Application de méthodes d'analyse statistique univariée et multivariée à l'étude parallèle de critères chimiques, biochimiques, rhéologiques, microbiologiques et sensoriels du fromage d'emmental au moment de sa taxation. Partie I : Analyse de quelques profils de distribution, Chimia 46 (1992) 406-415.

[8] Bosset J.O., Gauch R., Mariaca R., Klein B., Comparison of various sample treatments for the analysis of volatile compounds by GC-MS: application to the Swiss Emmental cheese, Mitt. Gebiete Lebensm. Hyg. 86 (1995) 672-698.

[9] Chamba J.F., L'emmental, un écosystème complexe. Conséquences sur la sélection et l'utilisation des ferments, Sci. Aliments 20 (2000) 37-54.

[10] Chamba J.F., Perreard E., Contribution of propionibacteria to lypolysis of Emmental cheese, Lait 82 (2002) 33-44.
[11] Christensen J.E., Dudley E.G., Pederson J.A., Steele J.L., Peptidases and amino acid catabolism in lactic acid bacteria, Antonie van Leeuwenhoek 76 (1999) 217-246.

[12] Collomb M., Bütikofer U., Sieber R., Jeangros B., Bosset J.O., Composition of fatty acids in cow's milk fat produced in the lowlands, mountains and highlands of Switzerland using high-resolution gas chromatography, Int. Dairy J. 12 (2002) 649-659.

[13] Curioni P.M.G., Bosset J.O., Key odorants in various cheese types as determined by gas chromatography-olfactometry, Int. Dairy J. 12 (2002) 959-984.

[14] De Jong C., Badings H.T., Determination of free fatty acids in milk and cheese. Procedures for extraction clean up and capillary gas chromatographic analysis, J. High Resolut. Chromatogr. 13 (1990) 94-98.

[15] Drozd J., Vodáková Z., Koupil P., Systematic errors with the use of internal standard calibration in gas chromatographic headspace analysis, J. Chromatogr. A 518 (1990) $1-8$.

[16] Frohlich-Wyder M.T., Bachmann H.P., Casey M.G., Interaction between propionibacteria and starter/ non-starter lactic acid bacteria in Swiss-type cheese, Lait 82 (2002) 1-15.

[17] Helinck S., Le Bars D., Moreau D., Yvon M., Ability of thermophilic lactic acid bacteria to produce aroma compounds from amino acids, Appl. Environ. Microbiol. 70 (2004) 3855-3861.

[18] Hettinga D.H., Reinbold G.W., The propionic-acid bacteria-A review II. Metabolism, J. Milk Food Technol. 35 (1972) 358-372.

[19] Imhof R., Glattli H., Bosset J.O., Volatile organic compounds produced by thermophilic and mesophilic single strain dairy starter cultures, Lebensm. Wiss. Technol. 28 (1995) 78-86.

[20] Isolini D., Grand M., Glättli H., Selektivmedien zum Nachweis von obligat und fakultativ heterofermentativen Laktobazillen, Schweiz. Milchw. Forschung 19 (1990) 57-59.

[21] Kieronczyk A., Skeie S., Langsrud T., Yvon M., Cooperation between Lactococcus lactis and nonstarter lactobacilli in the formation of cheese aroma from amino acids, Appl. Environ. Microbiol. 69 (2003) 734-739.

[22] Klein N., Maillard M.B., Thierry A., Lortal S., Conversion of amino acids into aroma compounds by cell-free extracts of Lactobacillus helveticus, J. Appl. Microbiol. 91 (2001) 404-411.

[23] Kleinhenz J., Harper W.J., Lower molecular weight free fatty acids in full fat and low fat Swiss cheese, Milchwissenschaft 52 (1997) 622-625. 
[24] Kubickova J., Grosch W., Evaluation of flavour compounds of Camembert cheese, Int. Dairy J. 8 (1998) 11-16.

[25] Langler J.E., Day E.A., Quantitative analysis of the major free fatty acids in Swiss cheese, J. Dairy Sci. 49 (1966) 91-93.

[26] Langsrud T., Reinbold G.W., Flavor development and microbiology of Swiss cheese - A review. III. Ripening and flavor production, J. Milk Food Technol. 36 (1973) 593-609.

[27] Lawlor J.B., Delahunty C.M., Wilkinson M.G., Sheehan J., Relationships between the sensory characteristics neutral volatile composition and gross composition of ten cheese varietics, Lait 81 (2001) 487-507.

[28] Liu S.Q., Holland R., Crow V.L., Esters and their biosynthesis in fermented dairy products: a review, Int. Dairy J. 14 (2004) 923-945.

[29] Maarse H., Visscher C.A., Willemsens L.C., Nijssen L.M., Boelens M.H., in: Volatile Compounds in Food: qualitative and quantitative data, TNO Nutrition and Food Research, Zeist, The Netherlands, 1994.

[30] McSweeney P.L.H., Nursten H.E., Urbach G., Flavours and off-flavours in milk and dairy products, in: Fox P.F. (Ed.), Advanced Dairy Chemistry, Lactose, Water, Salts and Vitamins, Chapman \& Hall, London, UK, 1997, pp. 403-468.

[31] Noël Y., Boyaval P., Thierry A., Gagnaire V., Grappin R., Eye formation and Swiss-type cheeses, in: Law B.A. (Ed.), Technology of cheesemaking, Sheffield Academic Press Ltd, Sheffield, UK, 1999, pp. 222-250.

[32] Paulsen P.V., Kowalewska J., Hammond E.G., Glatz B.A., Role of microflora in production of free fatty acids and flavor in Swiss cheese, J. Dairy Sci. 63 (1980) 912-918.

[33] Preininger M., Grosch W., Evaluation of key odorants of the neutral volatiles of Emmentaler cheese by the calculation of odour activity values, Lebensm. Wiss. Technol. 27 (1994) 237-244.

[34] Preininger M., Warmke R., Grosch W., Identification of the character impact flavour compounds of Swiss cheese by sensory studies of models, Z. Lebensm. Unters. Forsch. 202 (1996) 30-34.

[35] Reps A., Hammond E.G., Glatz B.A., Carbonyl compounds produced by the growth of Lactobacillus bulgaricus, J. Dairy Sci. 70 (1987) 559-562.

[36] Richoux R., Faivre E., Kerjean J.R., Effet de la teneur en $\mathrm{NaCl}$ sur la fermentation du lactate par Propionibacterium freudenreichii dans des minifromages à pâte cuite, Lait 78 (1998) 319-331.

[37] Richoux R., Kerjean J.R., Caractérisation technologique de souches pures de bactéries propioniques : test en minifabrication de fromages à pâte cuite, Lait 75 (1995) 45-59.
[38] Rychlik M., Bosset J.O., Flavour and offflavour compounds of Swiss Gruyère cheese. Identification of key odorants by quantitative instrumental and sensory studies, Int. Dairy J. 11 (2001) 903-910.

[39] Rychlik M., Warmke R., Grosch W., Ripening of Emmental cheese wrapped in foil with and without addition of Lactobacillus casei subsp. casei. III. Analysis of character impact flavour compounds, Lebensm. Wiss. Technol. 30 (1997) 471-478

[40] Sherman J.M., The cause of eyes and characteristic flavor in Emmental or Swiss cheese, J. Bacteriol. 6 (1921) 370-392.

[41] Thierry A., Maillard M.B., Production of cheese flavour compounds derived from amino acid catabolism by Propionibacterium freudenreichii, Lait 82 (2002) 17-32.

[42] Thierry A., Madec M.N., Richoux R., Croissance des bactéries propioniques dans le fromage : comparaison de deux milieux de dénombrement, Lait 74 (1994) 161-171.

[43] Thierry A., Maillard M.B., Le Quéré J.L., Dynamic headspace analysis of Emmental aqueous phase as a method to quantify changes in volatile flavour compounds during ripening, Int. Dairy J. 9 (1999) 453-463.

[44] Thierry A., Maillard M.B., Yvon M., Conversion of L-leucine to isovaleric acid by Propionibacterium freudenreichii TL 34 and ITGP23, Appl. Environ. Microbiol. 68 (2002) 608-615.

[45] Thierry A., Maillard M.B., Hervé C., Richoux R., Lortal S., Varied volatile compounds are produced by Propionibacterium freudenreichii in Emmental cheese, Food Chem. 87 (2004) 439-446.

[46] Thierry A., Richoux R., Kerjean J.R., Isovaleric acid is mainly produced by Propionibacterium freudenreichii in Swiss cheese, Int. Dairy J. 14 (2004) 801-807.

[47] Thierry A., Richoux R., Kerjean J.R., Lortal S., A simple screening method for isovaleric acid production by Propionibacterium freudenreichii in Swiss cheese, Int. Dairy J. 14 (2004) 697-700.

[48] Urbach G., Contribution of lactic acid bacteria to flavour compound formation in dairy products, Int. Dairy J. 5 (1995) 877-903.

[49] Urbach G., The flavour of milk and dairy products: II. Cheese: contribution of volatile compounds, Int. J. Dairy Technol. 50 (1997) 79-89.

[50] Valence F., Deutsch S.M., Richoux R., Gagnaire V., Lortal S., Autolysis and related proteolysis in Swiss cheese for two $\mathrm{Lac}$ tobacillus helveticus strains, J. Dairy Res. 67 (2000) 261-271.

[51] Yvon M., Rijnen L., Cheese flavour formation by amino acid catabolism, Int. Dairy J. 11 (2001) 185-201. 